\title{
ROTASI KERJA, STRESS, KEPUASAN KERJA DAN KOMITMEN ORGANISASI DI PERBANKAN KOTA MALANG
}

\author{
Yuyuk Liana \\ STIE Malangkucecwara \\ Jl. Terusan Candi Kalasan Blimbing Malang Telp (0341) 491813
}

\begin{abstract}
The main objective of this study is to find out the direct effect between job rotation, work stress towards job satisfaction, and to find out the indirect effect between job rotation, work stress towards organizational commitment through job satisfaction. The population was 52 respondent of banking employees. The results of this study provided evidence that there was a significant effect between job rotation towards job satisfaction, work stress towards job satisfaction, and job rotation towards organizational commitment; whereas between work stress towards organizational commitment, and job satisfaction towards organizational commitment showed the insignificant effect.
\end{abstract}

Keywords: stress, kepuasan kerja, rotasi kerja.

Karyawan merupakan salah satu sumber daya manusia yang penting dalam organisasi atau perusahaan dalam mencapai tujuannya. Untuk itu kualitas sumber daya manusia harus diperhatikan termasuk di dalamnya adalah softskill yang dimilikinya. Dengan adanya persaingan bisnis yang sangat ketat pada saat ini maka perusahaan dituntut untuk dapat meningkatkan kualitas SDM sehingga dapat mempertahankan kelangsungan hidup. Faktor kepuasan kerja karyawan dalam suatu organisasi merupakan hal yang sangat penting. Karyawan yang mempunyai tingkat kepuasan kerja yang baik maka akan bekerja dengan rajin dan penuh inovatif atau berperilaku posotif terhadap pekerjaannya dan sebaliknya bagi karyawan dengan tingkat kepuasan kerja yang rendah maka prestasi kerja karyawan rendah dan bahkan aan berperilaku negatif terhadap pekerjaannya seeperti timbul rasa malas, tidak disiplin dalam bekerja, dll, di mana hal ini akan berpengaruh terhadap tujuan organisasi. Untuk itu organisasi atau perusahaan perlu memperhatikan masalah kepuasan kerja sehingga kelangsungan hidup perusahaan dapat dipertahankan. Kepuasan internal dan ekternal merupakan hal yang perlu menjadi perhatian bagi perusahaan sehingga akan diketahui tingkat kepuasan dari karyawan dalam perusahaan atau 
organisasi.

Rotasi pekerjaan akan memberikan dampak positif bagi karyawan karena dengan adanya perputaran pekerjaan tersebut akan menghindarkan rasa jenuh atau bosan terhadap pekerjaan yang dilaksanakan. Namun bagi karyawan yang sudah merasa mapan dengan posisi sekarang dalam pekerjaannya maka akan protes dengan adanya rotasi pekerjaan tersebut. Karena itu kebijakan seperti itu harus didasarkan pada data dan informasi akurat mengenai kinerja individu, pengalaman kerja di unit, keterlibatan pelatihan, dan perilaku karyawan (Mangkuprawira, 2009). Diharapkan dengan rotasi pekerjaan yang cukup baik maka akan menimbulkan kepuasan kerja bagi karyawan dalam organisasi sehingga lebih bergairah dalam melaksanakan aktivitas pekerjaan yang dilakukan sehari-hari dapat berjalan dengan baik. Selain itu dengan adanya rotasi pekerjaan akan meningkatan kemampuan dan keahlian bagi karyawan untuk dapat berkarya dengan lebih baik lagi.

Karyawan yang mengalami stres di tempat kerja maka akan berpengaruh terhadap kegiatan dalam melaksanakan pekerjannya. Apabila hal ini tidak segera di atasi maka akan berdampak terhadap kegiatan. Untuk itu perusahaan atau organisasi harus dapat mengelola karyawan dengan baik yaitu salah satunya adalah dengan mengendalikan tingkat stress kerja karyawan, sehingga karyawan dapat bekerja seperti semula dengan baik. Namun stress tidak selalu berdampak negatif bagi karyawan dan mempunyai nilai-nilai positif terutama pada saat stress tersebut menawarkan suatu perolehan yang memiliki potensi (Robbins, 2003).

Setiap perusahaan menginginkan bahwa sumber daya manusia yang ada dalam perusahaannya memiliki tingkat produktifitas yang tinggi dalam bekerja, karena dengan kondisi yang demikian perusahaan dapat mencapai tujuan yang diinginkan. Bentuk komitmen tidak hanya karyawan menetap cukup lama dalam perusahaan tetapi lebih dari itu mereka mau memberikan yang terbaik bagi perusahaan, bahkan bersedia mengerjakan sesuatu melampai batas yang diwajibkan perusahaan. Penelitian ini dilakukan di Bank-Bank yang ada di kota Malang-Batu. Bank selain melakukan perbaikan terhadap produk yang dihasilkan, namun juga harus melakukan peningkatan kualitas sumber daya manusia yaitu karyawan dalam organisasi dalam menghadapi banyaknya 
persaingan ketat dunia bisnis perbankan saat ini. Berdasarkan uraian di atas maka tujuan penelitian ini adalah (1) Untuk menguji pengaruh secara langsung antara rotasi pekerjaan/jabatan, stres kerja terhadap kepuasan kerja, (2) Untuk menguji pengaruh secara tidak langsung langsung antara rotasi pekerjaan/jabatan, stres kerja terhadap komitmen organisasi melalui kepuasan kerja.

\section{Rotasi Pekerjaan}

Karyawan yang bekerja terlalu lama dalam satu pekerjaan maka akan mengakibatkan adanya kebosanan, sehingga akan berpengaruh terhadap aktivitas sehari-hari dalam menjalankan tanggung jawabnya sebagai karyawan. Hal ini senada dengan pendapat dari Mangkuprawira (2009) bahwa tidak jarang kinerja kayawan mengalami fluktuasi. Kondisi seperti itu diduga ada hubungannya dengan terlalu lamanya seseorang dalam periode kerja di satu unit atau di satu pekerjaan saja. Akibatnya timbul kebosanan dan bahkan kejenuhan di kalangan mereka. Diharapkan dengan adanya rotasi kerja tersebut maka akan dapat mengurangi kobosanan bagi karyawan. Menurut pendapat dari Wahyudi (2002) "Job rotation atau perputaran jabatan merupakan suatu bentuk mutasi personal yang dilakukan secara horizontal, di mana pemindahan tenaga kerja dari satu posisi/jabatan/pekerjaan ke yang lain tetapi masih dalam tingkat atau level manajemen yang sama, sering diistilahkan pula sebagai transfer, dengan tujuan antara lain untuk menambah pengetahuan seorang tenaga kerja dan menghindarkan terjadinya kejenuhan".

Rotasi jabatan menjadi unsur yang penting yang harus diperhatikan oleh pihak perusahaan atau organisasi, karena dengan rotasi jabatan/pekerjaan ini maka dapat meningkatkan efesiensi dan efektifitas kerja karyawan dalam organisasi. Adapun tujuan dari rotasi jabatan menurut pendapat dari Wahyudi (2002) adalah sebagai berikut: (1) Menciptakan keseimbangan antara tenaga kerja dengan jabatan yang ada dalam organisasi, sehingga dapat menjamin terjadinya kondisi ketenagakerjaan yang stabil (personal stability), (2) Membuka kesempatan untuk pengembangan karir, (3) Memperluas dan menambah pengetahuan, (4) Menghilangkan kejenuhan terhadap suatu jabatan, (5) Memberikan imbalan terhadap prestasi kerja, (6) Membuka kesempatan 
terjadinya persaingan dalam meningkatkan prestasi kerja, (7) Sebagai pelaksanaan sanksi terhadap pelanggaran.

\section{Kepuasan Kerja}

Pengertian dari kepuasan kerja menurut Robbins (2003) adalah "Kepuasan Kerja (job satisfaction) merujuk pada sikap umum seorang individu terhadap pekerjaannya". Definisi tersebut sangat luas, bahwa pekerjaan seseorang lebih dari sekedar kegiatan mencolok menata kertas, menulis kode pemograman, menunggu konsumen, dll. Pekerjaan membutuhkan interaksi dengan rekan kerja dan para atasan; mematuhi peraturan-peraturan dan kebijksanaan-kebijaksanaan organisasi, memenuhi standart kinerja, hidup dengan suasana kerja yang seringkali kurang ideal, dan semacamnya. Pendapat dari Handoko (2001) kepuasan kerja adalah sebagai bentuk respon emosional menunjukkan perasaan yang menyenangkan berkaitan dengan pandangan karyawan terhadap pekerjaannya.

Ada beberapa faktor yang mempengaruhi kepuasan kerja menurut pendapat As'ad (1987) faktor kepuasan kerja meliputi faktor kepuasan finansial, faktor kepuasan fisik dan faktor kepuasan psikologi. Selanjutnya menurut pendapat dari Heidjrachman dan Husnan (2002) bahwa kepuasan kerja meliputi beberapa faktor yaitu mengenai kebutuhan dan keinginan pegawai, seperti gaji yang baik, pekerjaan yang aman, rekan sekerja yang kompak, penghargaan terhadap pekerjaan, pekerjaan yang berarti, kesempatan untuk maju, pimpinan yang adil dan bijaksana, pengarahan dan perintah yang wajar, dan organisasi atau tempat kerja yang dihargai oleh masyarakat.

\section{Komitmen Organisasi}

Pengertian dari komitmen organisasi menurut Robbins (2003) mengatakan bahwa komitmen seseorang pada organisasi adalah suatu keadaan di mana seorang karyawan memihak pada suatu organisasi tertentu dan tujuantujuannya, serta berniat memelihara keanggotaannya dalam organisasi itu. Selanjutnya menurut pendapat dari Luthan (2002) Organizational Commitment is an attitude about employee's loyalty to their organization and is an ongoing process through which organizational participant express their concern for the organization and it's continued succes and well being. Komitmen organisasi dapat dijelaskan juga 
adalah sebuah sikap mengenai kesetiaan karyawan kepada organisasinya dan sebuah proses yang berlangsung di mana para peserta organisasi mengungkapkan perhatiannya pada keberhasilan dan kesejahteraan organisasi secara terus menerus.

Pendapat dari Steers dan Porter (1983) membedakan faktor-faktor yang mempengaruhi komitmen, yaitu: (1) Karakteristik Personal, antara lain meliputi usia, masa jabatan, motif berprestasi, jenis kelamin, ras, dan faktor kepribadian. (2) Karakteristik Pekerjaan, meliputi kejelasan serta keselarasan peran, umpan balik, tantangan pekerjaan, otonomi, kesempatan berinteraksi, dan dimensi inti pekerjaan. (3) Karakteristik struktural terdiri dari derajat formalisasi, ketergantungan fungsional, desentralisasi, tingkat pastisipasi dalam pengambilan keputusan, dan fungsi kontrol dalam perusahaan. (4) Pengalaman bekerja. Pengalaman kerja dipandang sebagai kekuatan sosialisasi yang penting, yang mempengaruhi kelekatan psikologis karyawan terhadap perusahaan.

Ada beberapa bentuk dari komitmen organisasi menurut pendapat dari Meyer dan Allen dalam Handoko dkk (2001) bahwa tiga bentuk tersebut mempunyai aplikasi terhadap kelanjutan partisipasi karyawan dalam suatu organisasi. Adapun 3 bentuk tersebut meliputi: (1) Komitmen afektif (affective commitment), (2) Komitmen continuance (continuance commitment) dan (3) Komitmen normatif (normative commitment).

\section{Stress Kerja}

Pengertian stress kerja Arsenault dan Dolan (1983) mengemukakan bahwa stres kerja adalah kondisi psikologis yang tidak menyenangkan yang ditimbulkan karena karyawan merasa terancam yang menunjukkan ketidaksesuaian antara individu dengan tuntutan pekerjaan. Selanjutnya menurut Mangkuprawira (2009) stress adalah perasaan tertekan yang dialami oleh karyawan dalam menghadapi pekerjaan. Stress kerja tampak dari simptom antara lain: emosi yang tidak stabil, perasaan tidak tenang, suka menyendiri, sulit tidur, merokok yang berlebihan, tidak bisa rileks, cemas, tegang, gugup, tekanan darah meningkat, dan mengalami ganngguan pencernaan.

Ada beberapa faktor yang mempengaruhi sress kerja menurut pendapat dari Hasibuan (2000) antara lain meliputi: beban kerja yang sulit dan 
berlebihan, tekanan dan sikap pimpinan yang kurang adil dan wajar, waktu dan peralatan kerja yang kurang memadai, konflik antara pribadi dengan pimpinan atau dengan kelompok kerja, balas jasa yang terlalu rendah, masalah-masalah keluarga seperti anak, istri, mertua dan lain-lain. Pendapat lain yaitu dari Handoko (2001) bahwa kondisi kerja yang sering menyebabkan stress bagi karyawan adalah sebagai berikut: beban kerja yang berlebihan, tekanan atau desakan waktu, kualitas supervisi yang jelek, iklim politis yang tidak aman, umpan balik tentang pelaksanaan kerja yang tidak memadai, wewenang yang tidak mencukupi untuk melaksanakan tanggung jawab, kemenduaan peranan, frustasi, konflik antara pribadi dan antar kelmpok, perbedaan antara nilai-nilai perusahaan dan karyawan dan berbagai bentuk perubahan.

\section{METODE}

Beberapa peubah yang digunakan dalam penelitian ini adalah rotasi pekerjaaan/jabatan (X1), stress kerja (X2), kepuasan kerja $(\mathrm{X} 3)$ dan komitmen organisasi (X4). Untuk lebih jelasnya, maka model penelitian ini adalah seperti tampak pada gambar berikut:

\section{Gambar 1. Model Penelitian}

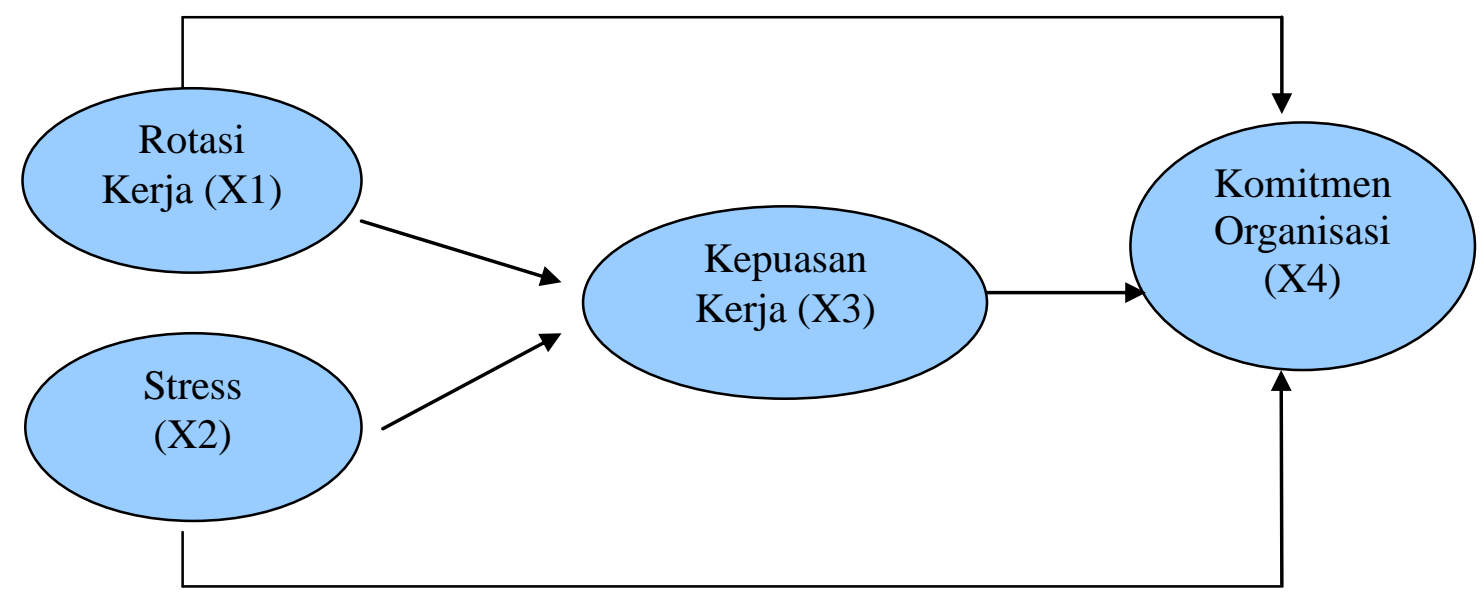

\section{Pengembangan Hipotesis}

Pengaruh langsung antara rotasi kerja, stress kerja terhadap kepuasan kerja

Rotasi kerja akan memberikan banyak pengetahuan, selain itu rotasi kerja/jabatan menghindarkan adanya kejenuhan atau kebosanan karyawan. 
Sehingga akan memberikan dampak terhadap kepuasan kerja karyawan dalam perusahaan. Selanjutnya dengan adanya rotasi kerja maka akan memberikan banyak keahlian bagi karyawan dalam beberapa departemen, hal ini dilakukan untuk mengurangi kelelahan yang terjadi dalam pekerjaannya. Hal ini senada dengan penelitian yang telah dilakukan oleh Humairah (2011) menyatakan bahwa rotasi pekerjaan, stress kerja dan kepuasan kerja secara bersama-sama dapat mempengaruhi komitmen organisasi serta penelitian yang telah dilakukan oleh Wen-Hseing Ho, Ying-Ling Shih dan Rong-Da Liang (2009) yang menyatakan bahwa rotasi kerja berpengaruh terhadap komitmen organisasi.

Stres pada karyawan akan berpengaruh terhadap tingkat kepuasan kerja karyawan dalam organisasi atau dengan kata lain semakin tinggi stres maka akan menurunkan tingkat kepuasan kerja karyawan (Elangovan, 2001). Hal ini sesuai dengan penelitian yang telah dilakukan oleh Muriman, et all (2008) yang menyatakan bahwa stress berpengaruh negatif terhadap kepuasan kerja karyawan. Stres kerja juga berdampak positif bagi karyawan apabila mereka menganggapnya sebagai suatu peluang bagi karyawan itu sendiri, artinya dengan stres tersebut mereka semakin termotivasi untuk segera menyelesaikan tugas yang diberikan kepada karyawan tersebut.

Berdasarkan pendapat di atas maka dapat dibuat hipotesis sebagai berikut:

H1: Terdapat pengaruh langsung antara rotasi kerja, stress kerja terhadap kepuasan kerja

\section{Pengaruh tidak langsung antara rotasi kerja, stress kerja terhadap komitmen organisasi melalui kepuasan kerja}

Rotasi pekerjaan akan menjadikan setiap karyawan dalam organisasi atau perusahaan dapat berkembang menjadi lebih baik, karena wawasan dan pengetahuan akan semakin bertambah. Selain itu juga dapat menghindarkan karyawan dari kejenuhan bekerja. Sedangkan stres kerja yang timbul pada karyawan, mungkin dapat juga disebabkan karena faktor beban kerja yang terlalu berlebihan, tuntutan tugas yang banyak, di mana hal ini akan membuat karyawan menjadi tidak maksimal dalam menyelesaikan tugasnya. Sedangkan komitmen organisasi karyawan akan merasa betah tinggal di perusahaan tersebut, yang mungkin salah satunya karena lingkungan kerja yang nyaman 
adanya perhatian atasan terhadap bawahan dalam bekerja. Jadi rotasi pekerjaan/jabatan serta stres kerja akan berpengaruh terhadap komitmen organisasi dengan melalui kepuasan kerja karyawan. Dengan demikian kepuasan kerja karyawan harus terpenuhi dengan baik atau maksimal supaya rotasi kerja dapat berjalan dengan baik dan tidak timbul stres kerja yang terlalu berlebihan, di mana hal ini akan memberikan dampak pada komitmen karyawan pada organisasi.

Berdasarkan pendapat di atas maka dapat dibuat hipotesis sebagai berikut:

H2: Terdapat Pengaruh tidak langsung antara rotasi kerja, stress kerja terhadap komitmen organisasi melalui kepuasan kerja

Sedangkan populasi dalam penelitian ini adalah seluruh karyawan bank yang ada di Malang Raya yang berjumlah 52 responden, yaitu karyawan bank bagian CS dan Teller yang ada di Malang Raya dan memiliki siklus rotasi tertentu dalam setiap tahun. Untuk mengukur sah atau valid tidaknya suatu kuisioner maka peneliti telah melakukan uji validitas dengan mengkorelasikan skor total item dengan skor masing-masing item dengan kriteria apabila probabilitas dari masing-masing item kurang dari 0,05, maka item tersebut dikatakan valid. Selain uji validitas, penelitian melakukan uji reliabilitas yang diuji dengan rumus koefisien alpha atau disebut dengan alpha cronbach. Ukuran yang dipakai bilamana nilai Cronbach Alpha di atas 0,6 dikatakan reliabel (Santoso,2002).

Adapun langkah-langkah untuk menguji masing-masing hipotesis dibagi menjadi dua yaitu pengujian hipotesis pertama dengan menggunakan analisis regresi berganda untuk mengetahui pengaruh rotasi pekerjaan/jabatan dan stress kerja terhadap kepuasan kerja. Adapun persamaan regresinya adalah :

Kepuasan kerja $(X 4)=\beta_{0}+\beta_{1}$ Rotasi pekerjaan $(X 1)+\beta_{2}$ Stres kerja $(X 2)$

Pengujian hipotesis kedua menggunakan analisis berganda untuk mengetahui pengaruh rotasi pekerjaan dan stress kerja terhadap komitmen organisasi melalui kepuasan kerja. Persamaan regresinya adalah sebagai berikut:

Komitmen organisasi $(X 4)=\beta_{0}+\beta_{1}$ rotasi pekerjaan $(X 1)+\beta_{2}$ Stres kerja $(X 2)+$ $\beta_{3}$ kepuasan kerja (X3) 


\section{HASIL DAN PEMBAHASAN}

Dari hasil uji validitas instrumen dapat dilihat pada hasil matrik korelasi skor item dengan skor total pada masing-masing variabel, dimana nilai probabilitas masing-masing item dari tabel 1 sampai dengan tabel 4 menunjukkan angka kurang dari 0,05 sehingga dapat disimpulkan bahwa item tersebut adalah valid. Untuk lebih jelasnya dapat dilihat pada tabel berikut :

Tabel 1. Uji Validitas Variabel Rotasi Pekerjaan/Jabatan

\begin{tabular}{|c|c|c|c|}
\hline $\begin{array}{c}\text { Hubungan antar } \\
\text { item }\end{array}$ & Koef. Korelasi & Probabilitas & Keterangan \\
\hline Skor X1.1 - total X1 & 0.651 & 0.000 & Valid \\
Skor X1.2 - total X1 & 0.851 & 0.000 & Valid \\
Skor X1.3 - total X1 & 0.764 & 0.000 & Valid \\
Skor X1.4 - total X1 & 0.795 & 0.000 & Valid \\
Skor X1.5 - total X1 & 0.735 & 0.000 & Valid \\
\hline
\end{tabular}

Sumber: data diolah

Tabel 2. Uji Validitas Variabel Stress Kerja

\begin{tabular}{|c|c|c|c|}
\hline $\begin{array}{c}\text { Hubungan antar } \\
\text { item }\end{array}$ & Koef. Korelasi & Probabilitas & Keterangan \\
\hline Skor X2.1 - total X2 & 0,794 & 0.000 & Valid \\
Skor X2.2 - total X2 & 0,609 & 0.000 & Valid \\
Skor X2.3 - total X2 & 0,826 & 0.000 & Valid \\
Skor X2.4 - total X2 & 0,577 & 0.000 & Valid \\
Skor X2.5 - total X2 & 0,819 & 0.000 & Valid \\
Skor X2.6 - total X2 & 0,812 & 0.000 & Valid \\
Skor X2.7 - total X2 & 0,763 & 0.000 & Valid \\
Skor X2.8 - total X2 & 0,500 & 0.000 & Valid \\
Skor X2.9 - total X2 & 0,277 & 0,047 & Valid \\
\hline
\end{tabular}

Sumber: data diolah

Tabel 3. Uji Validitas Variabel Kepuasan Kerja

\begin{tabular}{|c|c|c|c|}
\hline $\begin{array}{c}\text { Hubungan antar } \\
\text { item }\end{array}$ & Koef. Korelasi & Probabilitas & Keterangan \\
\hline Skor X3.1 - total X3 & 0,796 & 0.000 & Valid \\
Skor X3.2 - total X3 & 0,724 & 0.000 & Valid \\
Skor X3.3 - total X3 & 0,823 & 0.000 & Valid \\
Skor X3.4 - total X3 & 0,741 & 0.000 & Valid \\
Skor X3.5 - total X3 & 0,746 & 0.000 & Valid \\
Skor X3.6 - total X3 & 0,527 & 0.000 & Valid \\
Skor X3.7 - total X3 & 0,796 & 0.000 & Valid \\
Skor X3.8 - total X3 & 0,724 & 0.000 & Valid \\
Skor X3.9 - total X3 & 0,823 & 0.000 & Valid \\
Skor X3.10- total X3 & 0,741 & 0.000 & Valid \\
\hline
\end{tabular}


Sumber: data diolah

Tabel 4. Uji Validitas Variabel Komitmen Organisasi

\begin{tabular}{|c|c|c|c|}
\hline $\begin{array}{c}\text { Hubungan antar } \\
\text { item }\end{array}$ & Koef. Korelasi & Probabilitas & Keterangan \\
\hline Skor X4.1 - total X4 & 0,370 & 0.000 & Valid \\
Skor X4.2 - total X4 & 0.456 & 0.000 & Valid \\
Skor X4.3 - total X4 & 0.775 & 0.000 & Valid \\
Skor X4.4 - total X4 & 0.719 & 0.000 & Valid \\
Skor X4.5 - total X4 & 0.774 & 0.000 & Valid \\
Skor X4.6 - total X4 & 0.787 & 0.000 & Valid \\
Skor X4.7 - total X4 & 0.778 & 0.000 & Valid \\
Skor X4.8 - total X4 & 0.745 & 0.000 & Valid \\
Skor X4.9 - total X4 & 0.719 & 0.000 & Valid \\
Skor X4.10- total X4 & 0.720 & 0.000 & Valid \\
Skor X4.11-total X4 & 0.572 & 0.000 & Valid \\
\hline
\end{tabular}

Sumber: data diolah

Hasil uji reliabilitas menunjukkan nilai alpha lebih dari 0,6 sehingga dapat disimpulkan seluruh variabel reliable. Hasil selengkapnya dapat dilihat pada tabel berikut :

Tabel 5. Uji Reliabilitas

\begin{tabular}{|l|c|c|}
\hline \multicolumn{1}{|c|}{ Variabel } & Nilai alpha & Keterangan \\
\hline $\begin{array}{l}\text { Rotasi pekerjaan/jabatan } \\
(\mathrm{X} 1)\end{array}$ & 0.816 & Reliabel \\
Stress Kerja (X2) & 0.836 & Reliabel \\
Kepuasan Kerja (X3) & 0.909 & Reliabel \\
Komitmen Organisasi (X4) & 0.884 & Reliabel \\
\hline
\end{tabular}

Sumber: data diolah

Dari tabel 5 di atas dapat diketahui semua variabel mempunyai nilai alpha di atas 0,6 sehingga dapat disimpulkan bahwa seluruh variabel adalah reliabel. Dalam penelitian ini hipotesis 1 adalah terdapat pengaruh langsung antara rotasi pekerjaan, stres kerja terhadap kepuasan kerja. Dari hasil regresi diperoleh data sebagai berikut ini :

Tabel 6. Hasil regresi rotasi pekerjaan/jabatan, stres kerja terhadap kepuasan kerja (Pengujian Jalur-Model 1) 
Model Summary

\begin{tabular}{|l|r|r|r|r|}
\hline Model & $\mathrm{R}$ & $\mathrm{R}$ Square & $\begin{array}{r}\text { Adjusted } \\
\mathrm{R} \text { Square }\end{array}$ & $\begin{array}{r}\text { Std. Error of } \\
\text { the Estimate }\end{array}$ \\
\hline 1 & $.580^{\mathrm{a}}$ & .337 & .310 & 4.48187 \\
\hline
\end{tabular}

a. Predictors: (Constant), total.x2, total.x1

ANOV $R$

\begin{tabular}{|c|c|c|c|c|c|c|}
\hline Model & & $\begin{array}{l}\text { Sum of } \\
\text { Squares }\end{array}$ & df & Mean Square & $\mathrm{F}$ & Sig. \\
\hline \multirow[t]{3}{*}{1} & Regression & 403.926 & 3 & 134.642 & 4.052 & $.012^{\mathrm{a}}$ \\
\hline & Residual & 1594.997 & 48 & 33.229 & & \\
\hline & Total & 1998.923 & 51 & & & \\
\hline
\end{tabular}

a. Predictors: (Constant), total.x3, total. $x 1$, total.x2

b. Dependent Variable: total. $\times 4$

\section{Coefficient\$}

\begin{tabular}{|ll|r|r|r|r|r|}
\hline & & \multicolumn{2}{|c|}{$\begin{array}{c}\text { Unstandardized } \\
\text { Coefficients }\end{array}$} & $\begin{array}{c}\text { Standardized } \\
\text { Coefficients }\end{array}$ & & \\
\cline { 3 - 5 } Model & \multicolumn{1}{|c|}{$\mathrm{B}$} & Std. Error & \multicolumn{1}{|c|}{ Beta } & \multicolumn{1}{c|}{$\mathrm{t}$} & \multicolumn{1}{c|}{ Sig. } \\
\hline 1 & (Constant) & 12.338 & 5.435 & & 2.270 & .028 \\
& total.x1 & .392 & .150 & .303 & 2.605 & .012 \\
& total.x2 & .568 & .134 & .492 & 4.228 & .000 \\
\hline
\end{tabular}

a. Dependent Variable: total.x3

Dari hasil perhitungan pada model di atas didapat model persamaan sebagai berikut ini:

Kepuasan kerja $(X 3)=\beta_{0}+\beta_{1}$ Rotasi pekerjaan $(X 1)+\beta_{2}$ Stres Kerja $(X 2)$

Jadi: Kepuasan kerja $(X 4)=12.338+0.392$ Rotasi pekerjaan $(X 1)+0.568$ stres kerja $(X 2)$ atau Kepuasan kerja $(X 4)=0.303$ rotasi pekerjaan $(X 1)+0.492$ stres kerja (X2).

Pengujian secara simultan yaitu variabelnya rotasi pekerjaan/jabatan dan stress kerja terhadap kepuasan kerja. Dengan berdasarkan hasil perhitungan regresi pada tabel diatas didapatkan suatu persamaan garis regresi sebagai berikut:

$$
\begin{aligned}
& X 3=\beta_{0}+\beta_{1} X_{1}+\beta_{2} X_{2}+\varepsilon_{2} \\
& X 3=12.338+0.303 X_{1}+0.492 X_{2}+\varepsilon_{2}
\end{aligned}
$$

Hasil uji secara simultan digunakan menggunakan uji $\mathrm{F}$ tabel ANOVA dapat dilihat pada tabel di atas. Dari tabel tersebut di atas diperoleh nilai F untuk 
model 1 sebesar 4.052 dengan nilai probabilitas (sig. F) $=0.012$. Karena nilai sig. $\mathrm{F}<0.05$ maka keputusan terhadap Ho ditolak dan pengujian secara simultan dapat dilakukan atau dilanjutkan.

Pengujian Secara individu atau parsial menggunakan uji $t$, dimana Rotasi pekerjaan/jabatan (X1) berkontribusi secara signifikan terhadap kepuasan kerja (X3), hal ini dapat dilihat pada tabel 6 di atas pada kolom sig. pada tabel di atas model 1 (rotasi pekerjaan/jabatan) didapat nilai sig. 0.012 kurang dari 0.05 maka Ho ditolak dan Ha diterima, artinya koefisien analisis jalur adalah signifikan. Jadi, rotasi pekerjaan berkontribusi secara signifikan terhadap kepuasan kerja, sehingga disimpulkan bahwa rotasi pekerjaan/jabatan berpengaruh signifikan terhadap kepuasan kerja.

Stres kerja berkontribusi secara signifikan terhadap kepuasan kerja. Terlihat pada tabel di atas pada kolom sig. pada tabel di atas model 1 (stres kerja) didapat nilai sig. 0.000 kurang dari 0.05 maka Ho ditolak dan Ha diterima, artinya koefisien analisis jalur adalah signifikan. Jadi, stress berkontribusi secara signifikan terhadap kepuasan kerja. Berdasarkan hasil analisis jalur model 1 (X1, X2, X3) yang terlihat bahwa tidak ada koefisien jalur yang tidak signifikan sehingga semua jalur adalah signifikan.

\section{Pengujian hipotesis kedua}

Dalam penelitian ini hipotesis 2 adalah terdapat pengaruh tidak langsung antara rotasi pekerjaan, stres kerja terhadap komitmen organisasi melalui kepuasan kerja . Dari hasil regresi diperoleh data sebagai berikut ini :

Tabel 7. Hasil regresi rotasi pekerjaan/jabatan, stres kerja terhadap komitmen organisasi melalui kepuasan kerja (Pengujian Jalur-Model 2)

\section{Model Summary}

\begin{tabular}{|l|r|r|r|r|}
\hline Model & $\mathrm{R}$ & $\mathrm{R}$ Square & $\begin{array}{c}\text { Adjusted } \\
\text { R Square }\end{array}$ & $\begin{array}{r}\text { Std. Error of } \\
\text { the Estimate }\end{array}$ \\
\hline 1 & $.450^{\mathrm{a}}$ & .202 & .152 & 5.76447 \\
\hline
\end{tabular}

a. Predictors: (Constant), total. $\times 3$, total. $x 1$, total. $\times 2$ 


\section{ANOV $A$}

\begin{tabular}{|ll|r|r|r|r|r|}
\hline \multicolumn{1}{|c|}{} & & Sum of & & & & \\
\hline 1 & Squares & df & Mean Square & F & Sig. \\
\hline & Regression & 403.926 & 3 & 134.642 & 4.052 & $.012^{\mathrm{a}}$ \\
& Residual & 1594.997 & 48 & 33.229 & & \\
& Total & 1998.923 & 51 & & & \\
\hline
\end{tabular}

a. Predictors: (Constant), total. $\times 3$, total. $x 1$, total.x2

b. Dependent Variable: total. $x 4$

\section{Coefficients $^{\mathrm{a}}$}

\begin{tabular}{|c|c|c|c|c|c|c|}
\hline \multirow{2}{*}{\multicolumn{2}{|c|}{ Model }} & \multicolumn{2}{|c|}{$\begin{array}{c}\text { Unstandardized } \\
\text { Coefficients }\end{array}$} & \multirow{2}{*}{$\begin{array}{c}\begin{array}{c}\text { Standardized } \\
\text { Coefficients }\end{array} \\
\text { Beta }\end{array}$} & \multirow[b]{2}{*}{$t$} & \multirow[b]{2}{*}{ Sig. } \\
\hline & & B & Std. Error & & & \\
\hline & (Constant) & 18.894 & 7.348 & & 2.571 & .013 \\
\hline & total. $x 1$ & .350 & .206 & .233 & 1.694 & .097 \\
\hline & total. $\times 2$ & 161 & .202 & .120 & .798 & .429 \\
\hline & total. $\times 3$ & .297 & .184 & .256 & 1.618 & .112 \\
\hline
\end{tabular}

a. Dependent Variable: total. $x 4$

Komitmen organisasi $(X 4)=\beta_{0}+\beta_{1}$ rotasi pekerjaan $(X 1)+\beta_{2}$ Stres kerja $(X 2)+$ $\beta_{3}$ kepuasan kerja (X3)

Komitmen organisasi $(X 4)=18.894+0.350$ rotasi pekerjaan $(X 1)+0.161$ stres kerja $(\mathrm{X} 2)+0.297$ kepuasan kerja $(\mathrm{X} 3)$

Atau

Komitmen organisasi $(X 4)=0.233$ rotasi pekerjaan $(X 1)+0.120$ stres kerja $(X 2)$

+0.256 kepuasan kerja (X3)

Dengan demikian dapat ditentukan besarnya pengaruh masing-masing dari jalur persamaan sebagai berikut:

\section{Gambar 2}

Hasil Uji Analisis Path

P3 0.233(0.097)

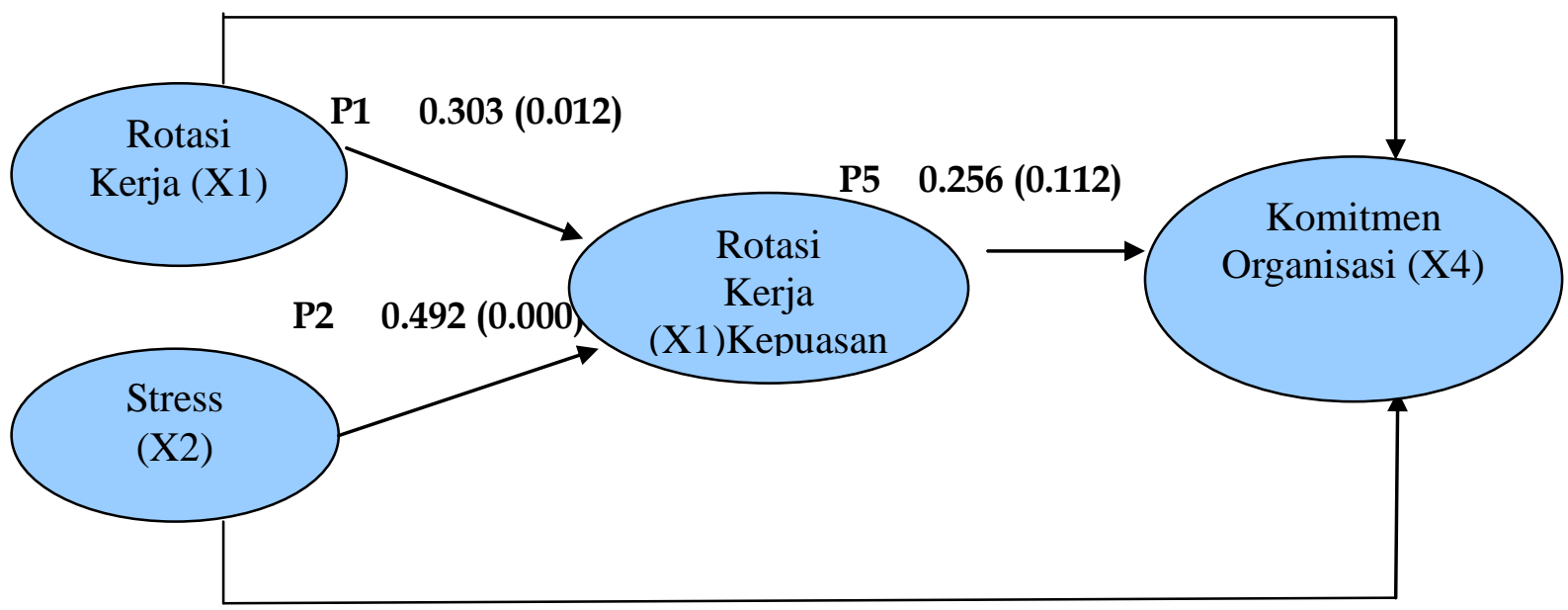


Berdasarkan uraian hasil analisis di atas, diperoleh nilai koefisien jalur stres kerja (X2) terhadap komitmen organisasi dengan nilai sig sebesar 0.429 yang berarti stress kerja tidak berpengaruh signifikan terhadap komitmen. Selain itu, koefesien jalur kepuasan kerja (X3) terhadap komitmen organisasi (X4) dengan nilai sig sebesar 0.112 yang berarti kepuasan kerja tidak berpengaruh signifikan terhadap komitmen organisasi. Karena terdapat variabel tidak tidak signifikan yaitu yaitu stres kerja (X2) terhadap komitmen organisasi (X4), serta jalur Kepuasan kerja (X3) terhadap komitmen organisasi (X4) maka perlu diperbaiki melalui metode trimming, yaitu dengan mengeluarkan jalur yang tidak signifikan dari analisisnya.

\section{Gambar 3}

Hasil uji perubahan analisis path

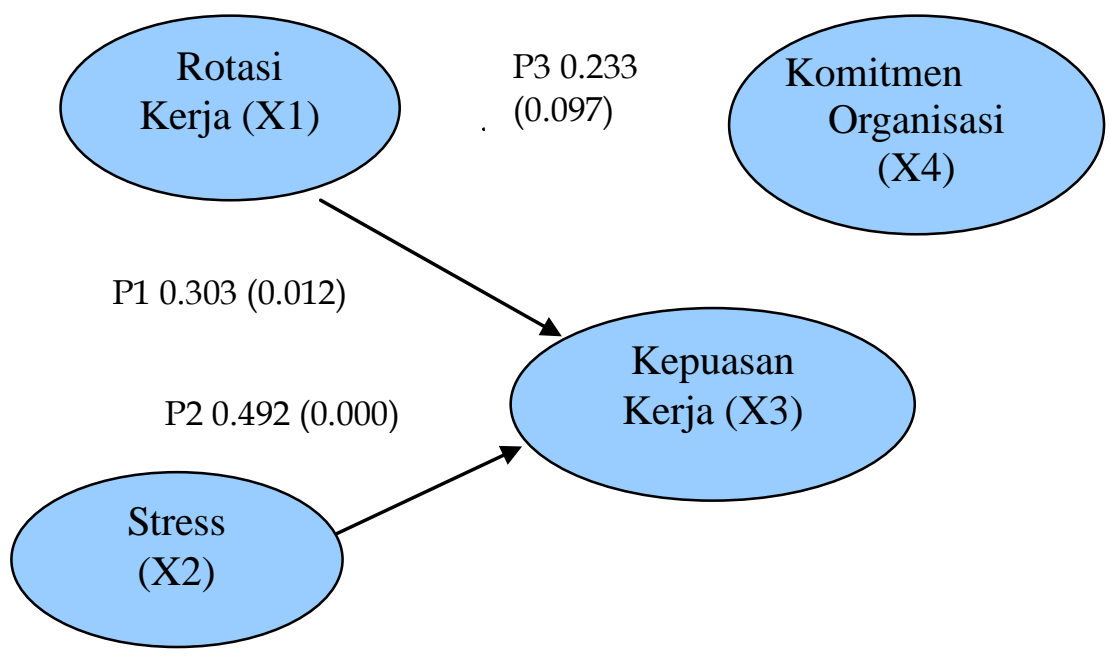

\section{Koefesien determinasi}

Total keragaman data dijelaskan dengan menggunakan formula sebagai berikut ini: $\mathrm{Rm}=1-\mathrm{P}^{2}{ }_{\mathrm{e} 1} \mathrm{P}^{2}{ }_{\mathrm{e} 2 \ldots .} \mathrm{P}_{\mathrm{ep}}$

Berdasarkan perhitungan maka dapat ditentukan koefesien determinasi total sebagai berikut ini: $\mathrm{R}^{2} \mathrm{~m}=1-(0.814)^{2} \cdot(0.893){ }^{2}$

$$
\begin{aligned}
& \mathrm{R}^{2} \mathrm{~m}=1-0.528 \\
& \mathrm{R}^{2} \mathrm{~m}=0.472
\end{aligned}
$$


Artinya keragaman data yang dapat dijelaskan oleh model tersebut adalah sebesar $47,2 \%$ atau dengan kata lain informasi yang terkandung dalam data adalah sebesar $47,2 \%$ dapat dijelaskan oleh model tersebut. Sedangkan sisanya dijelaskan oleh variabel lain yan belum ada di dalam model dan error.

Berdasarkan uraian hasil analisis di atas, diperoleh nilai koefisien jalur stres kerja (X2) terhadap komitmen organisasi dengan nilai sig sebesar 0.429 yang berarti stress kerja tidak berpengaruh signifikan terhadap komitmen, Selain itu, koefesien jalur kepuasan kerja (X3) terhadap komitmen organisasi (X4) dengan nilai sig sebesar 0.112 yang berarti kepuasan kerja tidak berpengaruh signifikan terhadap komitmen organisasi. Karena terdapat variabel tidak tidak signifikan yaitu yaitu stres kerja (X2) terhadap komitmen organisasi (X4), serta jalur Kepuasan kerja (X3) terhadap komitmen organisasi (X4) maka perlu diperbaiki melalui metode trimming, yaitu dengan mengeluarkan jalur yang tidak signifikan dari analisisnya.

\section{Metode Trimming}

Uji validitas koefesien path pada seiap jalur untuk pengaruh langsung adalah dengan persamaan regresi, menggunakan nilai $p$ dari uji $t$, yaitu pengujian koefesien regresi peubah dibakukan secara parsial. Berdasarkan teori trimming, maka jalur-jalur yang non signifikan dibuang, sehingga diperoleh model yang didukung oleh data yang empirik. Dari hasil pengujian, diketahui bahwa tidak seluruh variabel memiliki pengaruh signifikan, sehingga model berubah menjadi seperti gambar di bawah ini:

\section{Gambar 4}

Hasil uji perubahan analisis path

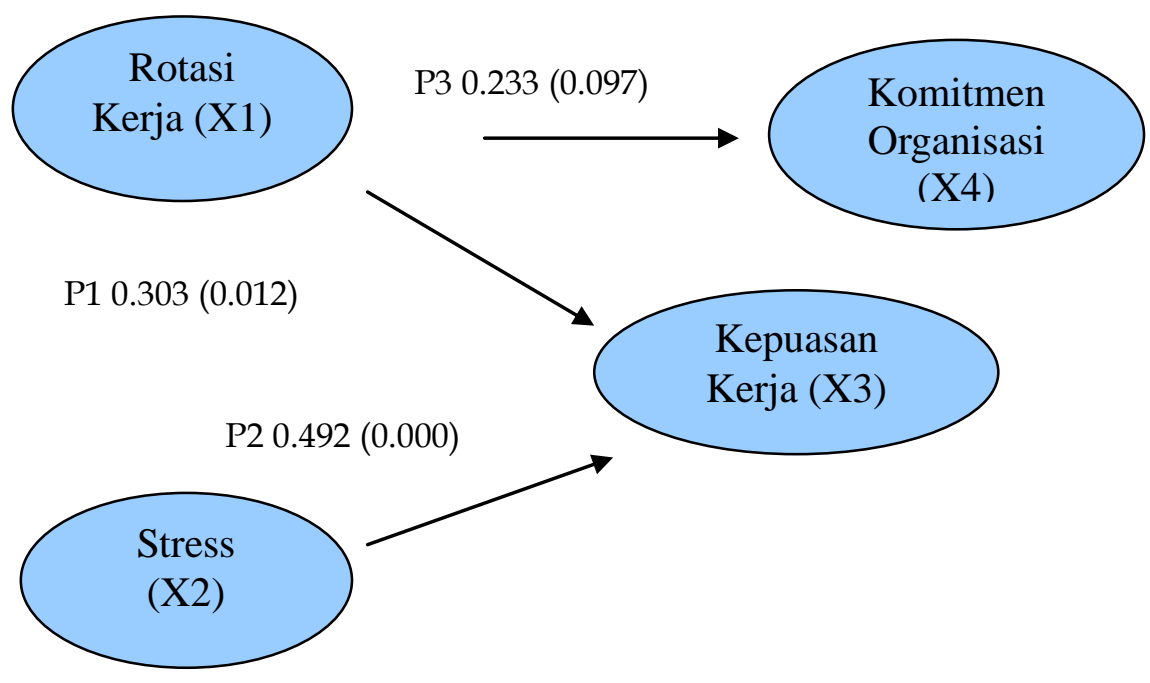




\section{Interpretasi hipotesis pertama.}

Hipotesis pertama adalah terdapat pengaruh langsung antara rotasi pekerjaan, stres kerja terhadap kepuasan kerja. Berdasarkan hasil analisis regresi diperoleh beta unstandardized untuk mengetahui pengaruh variabel rotasi kerja terhadap kepuasan kerja sebesar 0.303 dan $p=0.012$. Jadi dengan adanya rotasi pekerjaan/jabatan dalam perusahaan maka diharapkan kepuasan kerja karyawan juga akan meningkat. Rotasi pekerjaan yang baik akan memberikan dampak positif bagi karyawan, seperti dengan adanya rotasi akan menambah wawasan pengetahuan dan kemampuan karyawan dalam bekerja. Jadi karyawan tidak hanya menguasai satu bidang saja tetapi dapat menguasai beberapa bidang yang hal tersebut apabila dikembangkan terus maka akan menambah nilai bagi karyawan yang bersangkutan. Selain itu karyawan yang mau menerima rotasi kerja juga akan menambah pengetahuannya karena rotasi pekerjaan juga merupakan bagian dari pelatihan kerja bagi karyawan. Dengan adanya unsur pelatihan tersebut akan membantu karyawan untuk memperoleh tingkat efektifitas dalam menjalankan pekerjaannya baik untuk saat ini maupun saat yang akan datang dengan adanya pengembangan dalam kecakapan, ketelitian, ketelatenan, peningkatan pengetahuan atau semakin matang dalam berpikir dan bertindak terutama dalam pengambilan keputusan. Hal ini senada dengan penelitian yang telah dilakukan oleh Wen-Hseing Ho, Ying-Ling Shih dan RongDa Liang (2009), yang menyatakan dari hasil penelitiannya bahwa rotasi kerja mempunyai dampak positif terhadap kepuasan kerja karyawan.

Selanjutnya stres kerja juga akan berdampak positif terhadap komitmen kepuasan kerja. Berdasarkan hasil analisis regresi diperoleh beta unstandardized untuk mengetahui pengaruh variabel stres kerja terhadap kepuasan kerja sebesar 0.492 dan $p=0.000$. Stres tidak dipandang sebagai hal yang negatif dalam bekerja melainkan sebagai hal yang positif. Misalnya dengan banyaknya beban atau tugas tersebut maka karyawan justru merasa tertantang dalam menyelesaikan tugas yang dibebankan kepada dirinya. Hal ini aka semakin membuat karyawan menjadi lebih berpikir kreatif dalam menyelesaikan pekerjaannya. Selanjutnya stres kerja berdampak positif terhadap karyawan, apabila mereka 
mengangapnya sebagai suatu peluang, artinya dengan adanya stres maka mereka menjadi termotivasi untuk segera menyelesaikan pekerjaannya sehingga kepuasan kerja karyawan dapat dipertahankan. Hal ini senada dengan penelitian yang telah dilakukan oleh (Puspita dan Ratih, 2006) bahwa peran stres dapat membantu seseorang dalam meningkatkan kepuasan kerja seseorang. Karena dengan meningkatnya stres pada seseorang maka kadangkala dapat meningkatkan prestasi kerja ke arah yang lebih baik. Dengan stres seseorang semakin terpacu untuk mengerahkan segala kemampuan dan sumberdayasumberdaya yang dimilikinya agar dapat memenuhi persyaratan dan kebutuhan kerja.

\section{Interpretasi hipotesis kedua}

Hipotesis kedua adalah terdapat pengaruh tidak langsung antara rotasi kerja dan stres kerja terhadap komitmen organisasi melalui kepuasan kerja. Secara simultan di peroleh nilai signifikasi sebesar 0.012. Hal ini menujukkan bahwa secara bersama-sama yaitu variabel rotasi pekerjaan, stres kerja dan kepuasan kerja berpengaruh terhadap komitmen organisasi. Jadi dengan adanya rotasi pekerjaan bagi karyawan, maka mereka akan semakin mempunyai kemampuan yang maksmal sehingga skill atu keahlian karyawan akan semakin meningkat selain itu stres kerja dipandang sebagai hal yang positif, di mana hal ini justru memberikan motivasi bagi merek untuk berkembang menjadi lebih baik lagi sehingga komitmen karyawan dalam organisasi juga dapat dipertahankan. Namun rotasi pekerjaan dan stres kerja berpengaruh terhadap komitmen organisasi dapat melalui kepuasan kerja. Artinya dengan memperhatikan masalah rotasi pekerjaan stres kerja yang terjadi dalam perusahaan maka kepusan kerja karyawan dapat dipertahankan.

Berdasarkan hasil pengujian di atas diperoleh hasil bahwa pengaruh langsung antara rotasi pekerjaan terhadap komitmen organisasi sebesar 0.233 dan nilai signifikasi sebesar 0.097 artinya signfikan pada taraf $10 \%$. Sedangkan pengaruh stres kerja terhadap komitmen organisasi sebesar 0.120 dengan signifikasi sebesar 0.429 dan kepuasan kerja terhadap komitmen organisasi sebesar 0.256 dengan signifikasi sebesar 0.112. Besarnya nilai tersebut menujukkan pengaruh langsung dan tidak langsung. Dari hasil di atas diketahui yang mempunyai pengaruh yang paling besar adalah kepuasan kerja terhadap 
komitmen organisasi.

Faktor kepuasan kerja adalah merupakan salah satu bentuk dari implementasi atas terpenuhinya semua kebutuhan dan keinginan karyawan yang telah diperoleh dari pekerjaannya tersebut, sehingga dengan demikian diharapkan akan tumbuh komitmen karyawan terhadap organisasi semakin meningkat. Dengan kata lain bahawa tingkat kepuasan kerja yang baik maka berpengaruh terhadap komitmen organisasional, hal ini berarti mengandung pengertian bahwa komitmen organisasi dapat ditingkatkan apabila kepuasan kerja karyawan merasa terpenuhi dengan baik (Muhadi, 2007). Komitmen karyawan pada organisasi tersebut yaitu juga untu mengetahui tentang hubungan keeratan karyawan terhadap organisasi di mana mereka bekerja, sehingga dapat mencerminkan adanya keterlibatan serta kesetiaan karyawan terhadap organisasi, di mana hal ini akan berpengaruh terhadap pekerjaan yang dibebankan kepada karyawan yang bersangkutan yang diharapkan hasilnya lebih berkualitas lagi. Hal ini sejalan dengan penelitian yang telah dilakukan oleh Muhadi (2007) dan Wen-Hseing Ho, Ying-Ling Shih dan Rong-Da Liang (2009) yang menyatakan bahwa kepuasan kerja berpengaruh terhadap komitmen organisasi.

Sedangkan pengaruh tidak langsung antara rotasi kerja terhadap komitmen organisasi melalui kepuasan kerja diperoleh hasil sebesar $(\mathrm{P} 1 \times \mathrm{P} 3)=$ $0.303 \times 0.233=0.0705$ sedangkan pengaruh tidak langsung antara stres kerja terhadap komitmen organisasi melalui kepuasan kerja adalah sebesar $(\mathrm{P} 2 \times \mathrm{P} 4)=$ $0.492 \times 0.120=0.059$ Jadi dari hasil perhitungan di atas diperoleh pengaruh yang paling besar adalah pengaruh tidak langsung antara rotasi pekerjaan terhadap komitmen organisasi melalui kepuasan kerja. Dengan adanya rotasi pekerjaan/jabatan maka diharapkan akan banyak diperoleh pengetahuan dan wawasan dari karyawan dalam perusahaan selain itu faktor kejenuhan juga dapat dihindarkan, di mana kondisi ini akan memperkuat komitmen karyawan dalam organisasi, namun untuk itu kepuasan kerja karyawan juga perlu mendapatkan perhatian supaya semua variabel tersebut dapat terlaksana dengan baik.

\section{KESIMPULAN DAN SARAN}




\section{Kesimpulan}

Hasil penelitian membuktikan bahwa terdapat pengaruh antara rotasi pekerjaan terhadap kepuasan kerja, pengaruh antara stress kerja terhadap kepuasan kerja serta pengaruh rotasi pekerjaan terhadap komitmen organisasi yang semuanya memiliki jalur yang signifikan, sedangkan jalur yang tidak signifikan adalah stress kerja terhadap komitmen organisasi dan kepuasan kerja terhadap komitmen organisasi.

\section{Saran}

Berdasarkan hasil penelitian, pertama disarankan pihak perusahaan perlu memperhatikan rotasi jabatan, dengan tujuan dapat menghindarkan adanya kebosanan dalam pekerjaann, selain itu dengan rotasi peerjaan diharapkan pula pengetahuan dan wawasan serta kemampuan dari karyawan akan semakin meningkat karena memiliki banyak keahlian di beberapa bidang, dan dapat menemukan situasi yang baru dalam bekerja sehingga mereka akan semakin semangat dan mempunyai mitivasi yang tinggi dalam bekerja. Kedua, salah satu cara yang dilakukan dalam mengatasi stress adalah dengan melakukan pelatihan atau kegiatan lain yang dapat menyegarkan suasana kerja karyawan atau dengan cara memperhatikan faktor-faktor apa saja yang menyebabkan stres kerja sehinga dapat segera diatasi seperti memperhatikan suasana kerja yang nyaman, kondusif serta banyak memberikan motivasimotivasi pada karyawan. Ketiga, perlunya kesesuaian antara antara pekerjaan dengan kealian atau skill yang dimiliki oleh mereka, karyawan puas dengan lingkungan yang menyenangkan, situasi kerja yang kondusif dan lain-lain, di mana hal itu semua akan mendukung mereka dalam bekerja.

\section{DAFTAR RUJUKAN}

As'ad, 1987. Psikologi Industri. Yogyakarta: Liberty.

Arsenault, A. and Dolan, S. 1983. "The Rule of Personality, Occupation and Organization in Understanding The Relationships Between Job Stress, Performance and Absentuism." Journal of Development Psycology 56(4): 227240

Muriman, Chairul S, M.S. Idrus, Armanu Thoyib, Margono S. 2008. Pengaruh Budaya Organisasi dan Stres terhadap Komitmen Organisasi dan kepuasan 
Kerja (Studi di Kepolisian Negara RI Sektor, Kepolisian Negara RI Daerah Jawa Timur)

Elangovan, A.R. 2001. Causal Ordering of Stress, Satisfaction and Commitment, and ltention to Quit: astruc-tural equation analysis, Leadership and Organization Development Journal, Canada: Faculty of Busi ness, University of Victoria

Handoko, T. Hani, 2001, Manajemen Personalia dan Sumber Daya Manusia, Liberty, Yogyakarta.

Heidjrachman dan Husnan, Suad. 2002. Manajemen Personalia. Yogjakarta: BPFE.

Humairah 2011, Pengaruh rotasi pekerjaan, stres kerja dan kepuasan kerja terhadap komitmen organisasi (studi pada karyawan Biro Administrasi Universitas Widyagama Malang

Luthans, Fred, 2002. Organizational Behavior, 7th ed, McGraw-Hill, New York

Hasibuan, Malayu 2000. Manajemen Sumber Daya Manusia. Jakarta: CV Masagung.

Mangkuprawira, Tb. Sjafri, 2009. Horison Bisnis, Manajemen dan Sumberdaya Manusia. Bogor: PT. Gramedia.

Muhadi, 2007. Analisi Pengaruh Kepuasan Kerja Terhadap Komitmen Organisasional dalam Mempengaruhi Kinerja Karyawan (Studi pada Karyawan Administrasi Univeristas Diponegoro)

Steers, R.M and Porter, R. W.1983. Motivation and Work Behavior. New York: Mc Graw Hill.

Robins, Stephen P. 2003. Perilaku Organisasi. Jakarta: PT Indeks Kelompok Gramedia.

Puspitaningtyas dan Bernedet Ratih, 2006. Pengaruh Stres Kerja Terhadap Kepuasan Kerja Karyawan PT Sharp Electronics Indonesia.

Wahyudi, Bambang. 2002. Manajemen Sumber Daya Manusia, Bandung: CV Sulita Bandung

Wen-hsein Ho, Ching S Chang, Ying - Ling shih and Rong_Da Liang. 2009. Effect of job rotation and role sress among nurses on job satisfaction and organizational commitment. 